\title{
Bimbingan Teknis Kewirausahaan dan Pembuatan Rencana Usaha Jasa Wisata Curug Panganten Kabupaten Bandung Barat
}

\author{
Deddy Saefuloh ${ }^{1}$, Deddy Sobarna Sutaji ${ }^{2}$, Syifaa Novianti ${ }^{2}$, Rikantini Widiyanti ${ }^{2}$, \\ Sherly Raka Siwi Putri Utomo ${ }^{2}$, Dinarsiah Chendraningrum ${ }^{2}$ \\ ${ }^{1}$ Program Studi Pemasaran, Politeknik Negeri Bandung \\ ${ }^{2}$ Program Studi Usaha Perjalanan Wisata, Politeknik Negeri Bandung \\ Jl. Gegerkalong Hilir, Ciwaruga Kab Bandung Barat
}

Email: syifaa.novianti@polban.ac.id

\begin{abstract}
Abstrak - Artikel ini ditulis berdasarkan kegiatan Pengabdian Kepada Masyarakat (PKM) Politeknik Negeri Bandung yang bekerjasama dengan BUMDES Desa Padaasih Kabupaten Bandung Barat untuk memberikan solusi atas permasalahan pengembangan BUMDES dalam pengelolaan usaha jasa wisata Curug Panganten. BUMDES Desa Padaasih memiliki masalah yang mencakup keterbatasan sumber daya manusia desa terkait pengetahuan dan wawasan kewirausahaan untuk pengelolaan BUMDES serta belum adanya panduan rencana pengembangan usaha jasa wisata. Menindaklanjuti hal tersebut, telah dilaksanakan kegiatan Pengabdian Kepada Masyarakat oleh Politeknik Negeri Bandung dengan merancang Rencana Usaha Jasa Wisata Curug Panganten dan memberikan Bimbingan Teknis (BIMTEK) kepada pengurus dan penggerak BUMDES Desa Padaasih sebagai mitra. Kegiatan ini telah menghasilkan pemahaman mitra tentang pengelolaan usaha wisata yang mencakup Pemasaran, Strategi Bisnis, Pengelolaan SDM, Pengelolaan Produk, Pengelolaan Operasional Teknis, dan Alat Pemasaran dan pembuatan dokumen Rencana Usaha Jasa Wisata sebagai panduan agar BUMDES Desa Padaasih Cisarua KBB dapat mengembangkan usaha wisata guna meningkatkan perekonomian desa.
\end{abstract}

Kata Kunci - Rencana Usaha Jasa Wisata, Kewirausahaan, BUMDES, Bimbingan Teknis

Abstract - This article was written based on the Bandung State Polytechnic Community Service (PKM) activities in collaboration with BUMDES Desa Padaasih, West Bandung Regency to provide solutions to the problems of developing BUMDES in managing the tourism business in Curug Panganten. The BUMDES Desa Padaasih has problems that include limited village human resources related to entrepreneurial knowledge and insights for the management of BUMDES and the absence of a guide to planning the development of a tourism service business. Following up on this, Community Service activities have been carried out by the Bandung State Polytechnic by designing a Tourism Business Plan and providing Technical Guidance (BIMTEK) to administrators and activists of Padaasih Village BUMDES as partners. This activity has resulted in partners' understanding of tourism business management which includes Marketing, Business Strategy, Human Resource Management, Product Management, Technical Operational Management, and Marketing Tools and the creation of a Tourism Service Business Plan document as a guide so that BUMDES Desa Padaasih Cisarua KBB can develop a tourism business for improve the village economy.

Keywords - Tourism Service Business Plan, Entrepreneurship, BUMDES, Technical Guidance

\section{PENDAHULUAN}

Desa merupakan sebuah wilayah yang berpotensi mendukung perekonomian suatu negara. Di dalam desa terdapat banyak sumberdaya seperti sumberdaya alam, budaya, masyarakat dan lingkungan yang dapat dikembangkan dan dimanfaatkan untuk mengembangkan desa terutama dalam peningkatan ekonomi desa, salah satunya dengan membentuk Badan Usaha Milik Desa (BUMDES) yang dikelola oleh pemerintah dan masyarakat desa. Tujuan BUMDES seperti dalam Permendesa PDT dan Transmigrasi No. 4/2015 adalah, untuk meningkatkan perekonomian desa, meningkatkan usaha masyarakat dalam pengelolaan potensi ekonomi desa [1]. Menurut UU No.5 tahun 2015 dalam pendirian dan pengembangan BUMDES, modal diperoleh dari Dana Desa (DD) yang diambil dari APBN.

BUMDES juga dapat dikembangkan dengan membuat rencana kerja sama usaha dengan pihak lain di luar Desa seperti kerjasama antar desa atau dengan pihak lainnya, untuk menciptakan peluang dan jaringan pasar yang dapat memenuhi kebutuhan sehari-hari msyarakat. Selain itu BUMDES juga dapat membuka lapangan kerja, meningkatkan kesejahteraan masyarakat melalui 
pertumbuhan dan pemerataan ekonomi desa, dengan meningkatkan pendapatan masyarakat desa yang berpengaruh pada pendapatan desa.

Namun pada kenyataannya hingga saat ini sebagian besar BUMDES termasuk BUMDES Padaasih yang akan menjadi Mitra dalam program Pengabdian Masyarakat ini masih sebatas berdiri dan belum memiliki aktivitas yang menghasilkan. Seperti yang dikemukakan Presiden Joko Widodo dalam rapat terbatas soal Dana Desa di Istana, Jakarta, Rabu (11/12/2019), bahwa terdapat 2.188 BUMDES mangkrak alias terbengkalai atau tidak beroperasi. Selain itu terdapat pula 1.670 BUMDES yang berjalan tapi belum optimal berkontribusi menggerakkan ekonomi desa. Untuk itu diperlukan perbaikan kinerja.

Dalam peningkatan kinerja BUMDES Sumber daya manusia (SDM) desa menjadi persoalan penting dalam pengembangan dan pengelolaan BUMDES. Hal ini terkait keterbatasan pengetahuan dan wawasan masyarakat desa yang berpengaruh pada kualitas pengelolaan BUMDES agar tidak dikelola serampangan ataupun menjadi lahan korupsi aparat atau kerabat pemerintah desa yang dapat merugikan negara mengingat BUMDES merupakan sektor yang prioritas dibiayai oleh Dana Desa yang setiap tahun mengalami peningkatan.

\section{ANALISIS SITUASI}

Desa Padasih Cisarua yang terletak di Kabupaten Bandung Barat merupakan salah satu desa yang belum maksimal dalam mengelola aktivitas usaha yang dikelola oleh BUMDes. Desa ini memiliki banyak potensi yang dapat dikembangkan salah satunya adalah potensi wisata Curug Panganten yang berada pada ketinggian 1050 Mdpl dengan tinggi kurang lebih 50 meter, dengan mudah bisa dijangkau dari arah Jalan Ciawitali Cimahi atau dari Jalan Cihanjuang Cimahi. Curug adalah Bahasa Sunda untuk air terjun, Curug ini memiliki keindahan alam luar biasa dan menyimpan cerita yang sangat melegenda bagi masyarakat di sekitarnya. Terdapat dua versi mitos, pertama alkisah dahulu ada sepasang pengantin baru yang jatuh terpeleset dan terbawa arus air terjun, ada juga yang mengisahkan bahwa mereka bukan jatuh terpeleset melainkan bunuh diri bersama. Versi kedua mengapa disebut Curug Panganten karena air terjuan berasal dari dua sungai yang berdampingan.

Karena itu Curug Panganten ini menarik para wisatawan lokal untuk mengunjungi dan menikmati keindangannya seperti diperlihatkan dalam Gambar 1. Namun hingga saat ini belum ada pengelolaan terpadu dan BUMDES di desa ini dan masih belum beroperasi secara optimal. Hal ini terkait dengan keterbatasan pengetahuan dan wawasan masyarakat sebagai pelaksana terkait pengelola BUMDES. Sehingga BUMDES belum dapat memberikan benefit ekonomi yang dapat meningkatkan kesejahteraan masyarakat setempat. Berdasarkan hal tersebut permasalahan yang dihadapi mitra (pengelola BUMDES Padaasih) dan disepakati bersama adalah :

a. Keterbatasan Sumber Daya Manusia (SDM) desa terkait pengetahuan dan wawasan kewirausahaan untuk pengelolaan BUMDES.

b. Kurangnya pemahaman pengelolaan usaha jasa wisata BUMDES

c. Belum adanya panduan rencana pengembangan usaha jasa wisata BUMDES

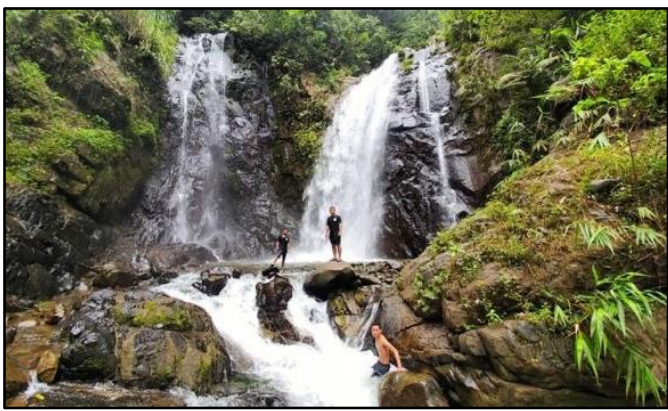

Gambar 1. Pemandangan Curug Panganten

\section{SOLUSI DAN METODE PELAKSANAAN}

Keterbatasan Sumber Daya Manusia (SDM) desa terkait pengelolaan BUMDES yang membuat BUMDES belum bisa berkembang secara optimal menjadi landasan utama dalam menyelesaikan masalah yang dihadapi mitra. Padahal dengan adanya kemampuan dan wawasan SDM yang mumpuni dapat meningkatkan pengelolaam BUMDES dan mengatasi segala permasalahan yang terjadi. Tentunya kemampuan dan wawasan ini terkait erat dengan kualitas kinerja SDM yang menentukan arah pengembangan usaha BUMDES dimana SDM sebagai pelaksananya. BUMDES menjadi peluang untuk meningkatkan perekonomian masyarakat, yang bukan hanya mampu meningkatkan kesejahteraan sosial secara ekonomi, namun dapat membuka lapangan pekerjaan bagi masyarakat setempat, dan menjadi motor penggerak perubahan ekonomi di Desa Padaasih.

Untuk menyelesaikan masalah yang dihadapi masayarakat desa Padaasih, perlu dilakukan kegiatan pelatihan bagi masyarakat desa berupa :

a. Bimbingan teknis (BIMTEK) kewirausahaan untuk meningkatkan pengetahuan dan wawasan terkait pengelolaan dan pengembangan usaha maupun konsep kewirausahaan yang dapat diterapkan untuk meningkatkan pengelolaan BUMDES agar dapat berkembang dan menghasilkan benefit sosial dan ekonomi. 
b. Bimbingan teknis dalam pembuatan rencana usaha wisata Curug Panganten yang ada di wilayah desa Padaasih agar Curug ini dapat dimanfaatkan sebagai salah satu usaha wisata desa yang nantinya dapat dimanfaatkan oleh masyarakat bukan hanya sebagai penambah penghasilan desa, tapi juga bisa membuka lahan pekerjaan bagi masyarakat desa.

c. Penyusunan model usaha jasa wisata Curug Panganten

Adapun metode yang digunakan adalah presurvey untuk pemetaan masalah dan potensi Desa dan BUMDES, dilanjutkan dengan perumusan dan perancangan modul pelatihan. Tentu saja partisipasi mitra penting sekali dalam memberikan informasi serta permasalahan yang akurat didukung buktibukti baik administratif maupun kenyataan lapangan. Dilanjutkan pelaksanaan bimbingan teknis atau pelatihan bagaimana mengembangkan produk wisata Curug Panganten, dan bagaimana merancang kegiatan pemasaran dalam hal ini memilih dan merancang jenis promosi yang tepat.

Secara komprehensif pelatihan topik-topik tersebut dipadukan dalam paket pelatihan kewirausahaan yang merangsang dan menantang kreatifitas peserta agar menghasilkan pilihan ideide produk dan kegiatan pemasaran yang solutif dan tepat. Proses perangsangan kreatifitas ini termasuk dalam jenis metode design thinking [2] yang dalam pelatihan di atas akan dipakai untuk menghasilkan bukti kreatifitas peserta dalam bentuk berbagai model canvas misalnya Business Model Canvas dan lain-lain. Melalui metode design thinking tersebut peserta akan terlibat secara aktif mengeluarkan ideidenya bukan dalam bentuk lisan tetapi langsung menulis, menggambar, dan mengisi kolom-kolom untuk menjawab antara lain persoalan produk, pelayanan, pemasaran, sumber daya manusia, dan keuangan.

Proses evaluasi yang akan dilakukan untuk kegiatan pengabdian kepada masyarakat di atas mencakup evaluasi awal kegiatan (pra-evaluasi) dalam bentuk tertulis; selama kegiatan dalam bentuk observasi; dan evaluasi setelah kegiatan (pasca evaluasi) dalam bentuk tertulis serta feedback secara lisan, sehingga kegiatan bisa diarahkan sesuai rencana, serta diukur sejauh mana tujuan kegiatan dapat dicapai

\section{LUARAN}

Hasil kegiatan yang akan dilakukan memberi pemahaman bagi masyarakat desa, dalam merencanakan dan mengelola usaha BUMDES, sehingga pelaksana BUMDES dan seluruh masyarakat desa yang terlibat dapat:

a. Meningkatkan pengetahuan dan wawasan terkait pengelolaan dan pengembangan usaha maupun konsep kewirausahaan yang dapat diterapkan untuk meningkatkan pengelolaan BUMDES agar dapat berkembang dan menghasilkan manfaat sosial dan ekonomi

b. Mampu membuat perencanaan usaha wisata Curug Panganten yang ada di wilayah desa Padaasih agar Curug ini dapat dimanfaatkan sebagai salah satu usaha wisata desa yang nantinya dapat dimanfaatkan oleh masyarakat bukan hanya sebagai penambah penghasilan desa, tapi juga bisa membuka lahan pekerjaan bagi masyarakat desa.

c. Mampu membuat model pengelolaan usaha jasa wisata Curug Panganten.

d. Luaran lainnya adalah artikel ilmiah dalam jurnal nasional terakreditasi dan prosiding internasional.

\section{Bimbingan Teknis (BIMTEK) Kewirausahaan}

Untuk melaksanakan program Bimtek kewirausahaan dan pembuatan rencana usaha wisata Curug Panganten diperlukan materi terkait perencanaan kewirausahaan dan pengelolaan usaha BUMDES yang sesuai dengan kebutuhan dan potensi Desa Padaasih. Hal ini diperlukan agar pelaksanaan kegiatan dapat memberikan manfaat yang optimal terutama dalam pengelolaan BUMDES di bidang usaha jasa wisata menjadi lebih berkembang. Adapun modul pelatihan yang disampaikan pada kegiatan Bimtek ini antara lain:

\section{Modul Pemasaran}

Modul ini bertujuan membekali peserta agar bisa menentukan segmen pasar mana yang menjadi sasaran, kelebihan apa yang ditawarkan oleh lokasi wisata, jenis produk wisata apa saja yang akan ditawarkan, menetapkan berapa kisaran harga tiket, memilih alat promosi yang tepat, saluran distribusi apa yang cocok digunakan. Selain itu peserta dapat memahami pentingnya pemasaran dalam rangkaian kegiatan usaha.

Topik dalam modul pemasaran ini mencakup strategi pemasaran yakni segmentasi, targeting, positioning (STP), dan bauran pemasaran (7P), serta Business Model Canvas (BMC). Dalam proses STP dijelaskan bagaimana pasar wisata Curug Cimahi dikelompokkan ke dalam beberapa segmen berdasarkan demografis seperti umur, tingkat pendapatan, kelas sosia, tingkat pendidikan. Kemudian berdasarkan geografis yaitu asal wilayah antara lain kota Cimahi, Bandung, Bandung Raya, Propinsi Jawa Barat, dan DKI Jakarta dengan tidak menutup kemungkinan dari wilayah lain di Indonesia dan juga dari Luar Negeri. Segmentasi lain berdasarkan perilaku mencakup wisatawan yang punya hobi olah raga, tanaman, dan juga komunitas kerohanian. 


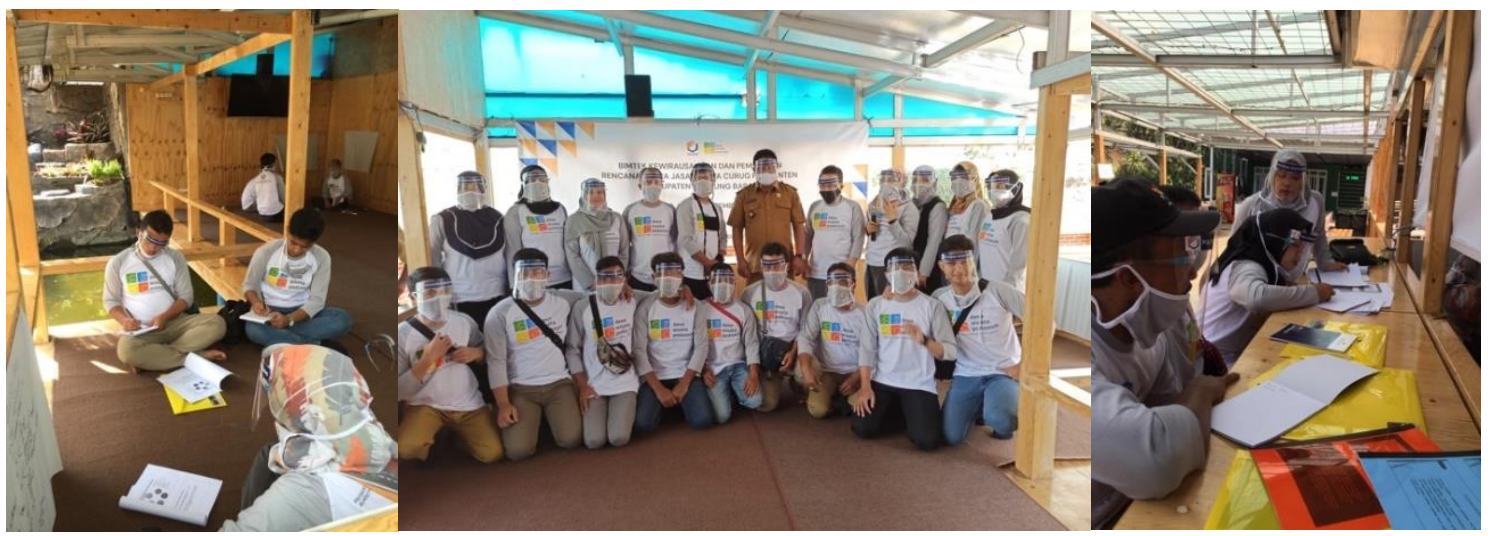

Gambar 2. Foto Kegiatan BIMTEK

Selanjutnya adalah tahapan targeting yaitu membidik segmen mana saja atau kombinasi segmen apa yang akan dilayani atau ditawari produk wisata. Kemudian terakhir adalah positioning yaitu apa yang akan diunggulkan sebagai keunikan yang akan diingat oleh wisatawan. Proses belajar mengarahkan peserta terlibat mengaplikasikan dengan cara menuliskan gagasan serta harapannya dalam kertas kanvas STP.Topik berikutnya adalah bauran pemasaran untuk bidang jasa wisata mencakup $7 \mathrm{P}$ yaitu produk, harga, tempat saluran distribusi, promosi, bukti fisik, personil yang terlibat, dan proses layanan. Peserta diajak untuk mengaplikasikan konsep 7P untuk wisata Curug Panganten dalam lembar kanvas 7P.

Topik terakhir adalah tentang model bisnis kanvas atau BMC di mana dijelaskan pemasaran berperan dalam setiap bagian BMC. Dijelaskan bahwa BMC merupakan suatu peta suatu bisnis, sehingga dengan melihat BMC peserta dapat memahami dan melihat peta kegiatan serta bagian apa saja yang harus ada dalam suatu usaha perusahaan. Masukan dari peserta yang dituliskan dalam kanvas STP dan 7P maka sebelumnya merupakan bahan yang sangat berguna untuk melengkapi rancangan BMC untuk usaha jasa wisata Curug Panganten.

\section{Modul Strategi Bisnis}

Modul Strategi Bisnis memiliki tujuan agar peserta pelatihan dapat mengetahui usaha pariwisata yang akan dijalankan menggunakan prinsip pemberdayaan kemasyarakatan. Melalui pemahaman prinsip tersebut masyarakat dapat mengoptimalkan sumber daya yang dimiliki juga mengoptimalkan keterlibatan masyarakat. Selain itu, masyarakat juga diharapkan dapat mengimplementasikan konsep kemitraan dalam mengembangkan Desa Padaasih menjadi tujuan pariwisata.
Ruang lingkup pelatihan strategi bisnis meliputi metode kemitraan Pentahelix dan pencapaian tujuan melalui metode OKR (Objective Key Result) [3]. Metode Pentahelix di Indonesia dikenal dengan strategi ABCGM yaitu Academy, Business, Community, Government, dan Media. Strategi ABCGM ini memungkinkan masyarakat desa untuk menggunakan kemitraan dalam mencapai tujuan pengembangan desa wisata. Pada kemitraan dengan akademisi dapat berupa berkolaborasi dan membuka pintu kerja sama dengan lembaga pendidikan dari berbagai level, seperti pemasaran kegiatan karyawisata, study tour, penelitian untuk perbaikan, pengembangan Sumber Daya Manusia, dan lainnya. Pada kemitraan dengan perusahaan/lembaga bisnis dapat berupa penghematan biaya bahan baku, distribusi produk, transfer teknologi, dan lainnya. Adapun kemitraan dengan komunitas mencangkup penguatan solidaritas dan identitas desa wisata dengan adanya aktivitas-aktivitas bersama komunitas seperti komunitas pencinta alam, komunitas berkebun, komunitas blogger pariwisata, dan lainnya. Kemitraan dengan pemerintah juga menjadi sangat penting seperti urusan perizinan, perlindungan penyelenggaraan, bantuan dana pemerintah, hingga dukungan promosi oleh dinas pariwisata. Terakhir adalah kemitraan dengan media yang menjadi kunci promosi desa wisata bagaimana dapat mendatangkan wisatawan dan mengenalkan objek menarik kepada masyarakat luar.

Sedangkan metode OKR digunakan dengan harapan masyarakat dapat memahami tujuan secara fokus per target yang ingin dicapai. Target disusun dengan fokus pada lingkup yang ingin dicapai sebagai bentuk Objective, seperti daya tarik, kunjungan wisatawan, ataupun kualitas promosi. Objective tersebut dapat dicapai dengan mempelajari indikator-indikator keberhasilan target yang disusun secara sistematis dan kuantitatif. Indikator keberhasilan ini disebut Key Result dengan sifat yang dapat diukur. Untuk memenuhi 
indikator keberhasilan diperlukan daftar kegiatan yang dilakukan hingga penentuan penanggung jawab dan durasi waktu penyelesaiannya.

\section{Modul Pengelolaan Sumber Daya Manusia}

Tujuan dari modul ini adalah membekali peserta tentang pemahaman akan penggunaan/pemanfaatan sumber daya manusia untuk mencapai tujuan organisasi. Adapun Fungsifungsi Manajemen Sumber Daya Manusia yang dipaparkan antara lain: 1) Staffing, 2) Pengembangan Sumber Daya Manusia. 3) Kompensasi dan Tunjangan Tambahan, 4) Kesehatan dan Keselamatan Kerja, 5) Hubungan Perburuhan [4].

Staffing adalah proses dimana suatu organisasi dapat menjamin bahwa selalu memiliki jumlah tenaga kerja dan tingkat ketrampilan yang tepat pada waktu yang dibutuhkan/tepat dalam mencapai tujuan organisasi. Staffing mencakup analisis Jabatan/pekerjaan, perencanaan sumber daya manusia, pengadaan pegawai/rekruitmen, menyeleksi pegawai. Sementara itu, recruitment (penarikan calon pegawai) merupakan suatu proses penarikan individu-individu pada suatu saat tertentu, dengan jumlah yang cukup, dan dengan kualifikasi yang tepat dan mendorong mereka untuk melamar pekerjaan kepada organisasi. Sumbersumber rekruitmen eksternal antara lain: sekolah menengah umum/atas dan sekolah kejuruan, community colleges, colleges dan universitas, para pesaing di pasar tenaga kerja, dan lain-lain.

Pengembangan Sumber Daya Manusia adalah fungsi utama manajemen sumber daya manusia yang terdiri dari bukan hanya pelihan dan pengembangan saja tetapi juga perencanaan karir individu, pengembangan organisasi, dan penilaian kinerja. Hal ini mencakup pelatihan, pengembangan, perencanaan karir, pengembangan organisasi, penilaian kinerja.

Kompensasi dan tunjangan tambahan menyangkut seluruh penghargaan yang diberikan kepada para pekerja atas balasan jasa yang diberikan terhadap perusahaan. Hal ini meliputi kompensasi yakni total dari seluruh penghargaan yang diberikan kepada para pegawai atas jasanya terhadap organisasi. Kompensasi terdiri dari kompensasi finansial langsung, kompensasi finansial tidak langsung, dan kompensasi non finansial.

Kesehatan dan keselamatan kerja menyangkut perlindungan pekerja dari luka akibat kecelakaan kerja dan Merujuk pada terbebasnya para pekerja dari sakit fisik dan mental Terakhir, hubungan perburuhan yang mencakup unionisasi dan perundingan kolektif, pertimbangan Hukum dan daya tarik unionisasi

\section{Modul Pengelolaan Produk}

Potensi suatu destinasi menjadi penting dalam pembuatan produk paket wisata. Potensi tersebut antara lain berupa atraksi wisata (alam, buatan, budaya, dll) ditunjang dengan fasilitas utama dan penunjang kegiatan wisata, selain itu produk wisata juga memerlukan dukungan dari industri pariwisata antara lain penyedia akomodasi, biro perjalanan wisata, perusahaan transportasi, restoran (penyedia makanan dan minuman aksesibilitas) dan juga dukungan pemerintah dan masyarakat yang berada di destinasi [5].

Produk wisata ini dapat dikemas menjadi sebuah paket wisata yang menarik dan banyak diminati sesuai dengan ekspektasi wisatawan. Modul ini bertujuan menggali produk wisata yang ada di destinasi kemudian mengelompokannya menjadi suatu tema dan beberapa paket wisata Berikut ini alur penyusunan pembuatan paket wisata yaitu:

1. Membagi dan mendeskripsikan tempat-tempat wisata di suatu destinasi berdasarkan informasi menggunakan data primer atau sekunder. Hal ini mencakup: 1) Aktivitas yang dilakukan, 2) Waktu di tempat wisata tersebut, 3) Fasilitas restoran, 4) Fasilitas akomodasi, 6) Fasilitas penunjang (Toilet, mushola, tempat sampah, ATM, Tempat souvenir, tempat parkir), 7) Harga tiket masuk destinasi, 8) Pelayanan (tour guide, tourism information center). 8) tandar keamanan \& Keselamatan (SOP dan Sapras keamanan)

2. Tour quotation (biaya paket perjalanan). Setelah mengidentifikasikan tempat-tempat wisata tersebut, maka membuat biaya paket perjalanan.

a. Biaya tetap (fixed cost) adalah biaya yang menjadi tanggungan kelompok wisatawan secara kolektif. Besarnya ditentukan oleh jumlahkelompok. Misalnya: tip pengemudi, ongkos parkir, waiter's tip, tour guide fee, transportasi dan lain-lain.

b. Biaya tidak tetap (variable cost). Biaya tidak tetap adalah biaya yang merupakan tanggungan peserta secara perorangan. Besarnya ditentukan oleh jumlah peserta, misalnya: airport tax, meals, entrance fee, dan lain-lain.

Dari komponen biaya per paket perjalanan, kemudian di mark-up kembali 10-20\% (tergantung kebijakan operator) sehingga menjadi harga jual yang mampu ditawarkan pada wisatawan 
3. Itinerary. Dokumen yang mengilustrasikan penyelenggaraan wisata. Manfaat itinerary bagi wisatawan dan pengelola adalah memastikan bahwa paket wisata tersebut sesuai dengan ekspektasi wisatawan dari segi program yang telah ditawarkan phak penyelenggara.

4.

Dengan modul pembuatan produk wisata khususnya paket wisata, diharapkan paket tersebut dapat memaksimalkan pengalaman wisatawan saat berkunjung ke suatu destinasi karena semua yang diperlukan dalam melakukan perjalanan telah ditangani oleh pihak yang professional. Keuntungan paket wisata yang dibuat oleh destinasi wisata dapat membuka lapangan kerja dan juga unit usaha bisnis di destinasi sehingga dapat memberikan pendapatan bagi penyelenggara dan juga meningkatkan citra dan kreatifitas destinasi atau pihak penyelenggara karena memaksimalkan sumber daya di wilayahnya.

\section{Modul Pengelolaan Operasional Teknis}

Pada modul ini, Peserta diberikan pelatihan terkait bagaimana teknis operasional dalam menjalankan kegiatan usaha wisata di Desa Pada Asih dalam hal ini adalah menjalankan paket wisata yang ada. Teknik Operational meliputi pelayanan dalam penjualan paket. Dengan teknis operasional penjualan paket, peserta diajarkan membuat form terkait penjualan paket yang berisi jenis paket (individu/family/grup) lalu durasi paket (hald day/one day) dan harga paket yang dibeli. Agar pembelian paket ini terdata dan dapat di evaluasi di akhir periode. Selain itu peserta juga diajarkan cara mengkoordinasikan tamu dan cara membagi tugas (dalam hal ini pengurus bumdes) yang meliputi tugas sebagai tour operation, tour guide, catering, dan sebagainya yang terkait dengan item yang dibeli dalam paket. Dalam hal ini peserta diajarkan membuat table yang berisi daftar nama petugas, peran dan tanggung jawabnya, informasi koneksi yang akan dihubungi selama kegiatan paket dan lokasi berkumpul wisatawan.

Peserta juga dilatih memandu wisata selama kegiatan berlangsung, pemanduan ini meliputi cara menerima tamu, menginterpretasikan suatu daya tarik, dan mengkoordinasikan tamu dari satu destinasi ke destinasi lain yang telah dibeli dalam paket. Selain itu peserta juga diajarkan bagaimana melayani tamu, mendengarkan keluhan dan menangani permasalahan tamu selama kegiatan berlangsung. Dalam pemaduan ini juga peserta diajarkan bagaimana membangun hubungan yang baik dan membuat kerjasama dengan pemilik tempat wisata di sekitar desa Pada Asih. Selain itu peserta juga diajarkan untuk membuat kegiatan wisata selain menarik bagi wisatawan seperti kegiatan edukatif, selfie atau belanja, tetapi juga diajarkan bagaimana bisa mengajak wisatawan untuk membeli produk hasil desa Pada Asih. Dan terakhir Modul ini juga melatih peserta dalam mengevaluasi kegiatan mulai dari evaluasi anggaran seperti pemasukan yang diterima, alokasi pemasukan, keuntungan alokasi keuntungan agar paket ini dapat dinikmati bukan hanya bagi pengelola (BUMDES) tapi juga masyarakat desa pada umumnya. Selain itu peserta juga diajarkan membuat kuesioner untuk peserta terkait evaluasi kegiatan yang meliputi petugas dan kegiatan yang dilakukan hari itu agar dapat dijadikan masukan kegiatan paket wisata berikutnya.

\section{Modul Alat Pemasaran}

Pada modul ini, peserta diberikan pelatihan mengenai penggunaan Canva dan pengoperasian Instagram. Canva adalah aplikasi desain grafis online yang mudah untuk digunakan, bahkan bagi pemula. Canva juga dapat diakses melalui perangkat desktop maupun mobile. Dengan Canva, pembuatan konten visual sebagai bagian dari pemasaran produk atau jasa wisata dapat dilakukan dengan hasil yang lebih professional. Beberapa desain alat pemasaran yang dapat dibuat melalui Canva antara lain: logo, poster, featured image blog, infografik, newsletter, konten media sosial, thumbnail Youtube, desain kemasan produk, invoice, banner iklan. Pada pelatihan menggunakan Canva ini, capaian pembelajaran yang diharapkan dari peserta antara lain: 1) Peserta mengetahui tentang Canva dan manfaatnya dalam pembuatan konten visual, 2) Peserta memahai fitur-fitur pada Canva, 3) Peserta dapat membuat contoh konten visual (flyer/poster/feeds) untuk pemasaran produk. Adapun metode yang dilakukan adalah peserta praktek dengan menggunakan laptop yang dibimbing langsung oleh fasilitator. Beberapa tahapan yang diajarkan meliputi membuat akun Canva, memilih template, mengatur teks, gambar, layout, hingga mengunduh hasil desain yang telah dibuat.

Setelah berhasil membuat konten visual, peserta selanjutnya diberikan paparan dan praktek tentang pengoperasian Instagram. Instagram merupakan salah satu media sosial yang sangat populer dan banyak diakses oleh berbagai kalangan. Instagram membantu pemasaran produk atau jasa wisata dengan biaya yang murah dan jangkauan yang luas [6]. Capaian pembelajran yang diharapkan antara lain: 1) Peserta mengetahui tentang Instagram dan manfaatnya dalam memasarkan destinasi wisata, 2) Peserta memahai fitur-fitur pada Instagram, 3) Peserta dapat mengoperasikan Instagram dalam memasarkan produk/jasa wisata. Hasil konten visual yang telah dibuat dari pelatihan Canva sebelumnya dipublikasi 
melalui media sosial Instagram. Beberapa tahapan yang diajarkan meliputi membuat akun Instagram (mengatur foto dan profil/bio), memposting foto dan video untuk Instagram feeds, memposting foto dan video untuk Instagram stories, mengikuti akun Instagram, hingga membalas atau mengomentari pertanyaan dari pengunjung pada posting.

\section{Dokumen Rencana Usaha Jasa Wisata Curug Panganten}

Selain pelaksanaan bimbingan teknis, luaran yang dihasilkan dari kegiatan Pengabdian Kepada Masyarakat ini adalah Rencana Usaha dan Model Pengelolaan Usaha Jasa Wisata Curug Panganten. Dokumen ini merupakan alat atau pedoman yang akan diserahterimakan kepada pihak BUMDES.

Rencana Usaha (Business Plan) untuk wisata Curug Panganten dimaksudkan sebagai panduan agar BUMDES Desa Padaasih Cisarua KBB dapat mengembangkan usaha wisata Curug Panganten serta wisata desa lainnya. Struktur business plan ini mencakup analisa SWOT, serta perencanaan usaha yang berkaitan dengan Pemasaran, Sumber Daya Manusia, Teknis Operasional, dan Keuangan. Terakhir ditambahkan Business Model Canvas (BMC). Bagian SWOT menganalisa kekuatan dan kelemahan internal BUMDES serta peluang dan ancaman dari lingkungan luar. Hasil SWOT ini akan menentukan perencanaan berikutnya. Bagian Pemasaran menjelaskan strategi Pemasaran yang mencakup tujuan Pemasaran, STP, serta bauran Pemasaran yang akan dipilih. Kemudian bagian SDM menjelaskan kebutuhan personil level manajemen dan operational, struktur organisasi, serta deskripsi kerja masing-masing. Bagian Teknis operasional mencakup prosedur dan teknis pelayanan untuk wisatawan. Bagian Keuangan memprediksi pendapatan dan pengeluaran yang layak. Terakhir bagian BMC memberikan gambaran semacam peta bisnis bagi usaha jasa wisata Curug Panganten serta wisata desa pendukung.

\section{KESIMPULAN}

Desa merupakan sebuah wilayah yang berpotensi mendukung perekonomian suatu negara. Di dalam desa terdapat banyak sumber daya seperti sumber daya alam, budaya, masyarakat dan lingkungan yang dapat dikembangkan dan dimanfaatkan untuk mengembangkan desa terutama dalam peningkatan ekonomi desa, salah satunya dengan membentuk Badan Usaha Milik Desa (BUMDES) yang dikelola oleh pemerintah dan masyarakat desa. Tujuan BUMDES adalah untuk meningkatkan perekonomian desa, meningkatkan usaha masyarakat dalam pengelolaan potensi ekonomi desa. Namun pada kenyataannya hingga saat ini sebagian besar BUMDES termasuk BUMDES Padaasih yang akan menjadi Mitra dalam program Pengabdian Masyarakat ini masih sebatas berdiri dan belum memiliki aktivitas yang menghasilkan. Hal tersebut dikarenakan keterbatasan Sumber Daya Manusia (SDM) desa terkait pengetahuan dan wawasan kewirausahaan untuk pengelolaan BUMDES, kurangnya pemahaman pengelolaan usaha jasa wisata BUMDES, belum adanya panduan rencana pengembangan usaha jasa wisata BUMDES.

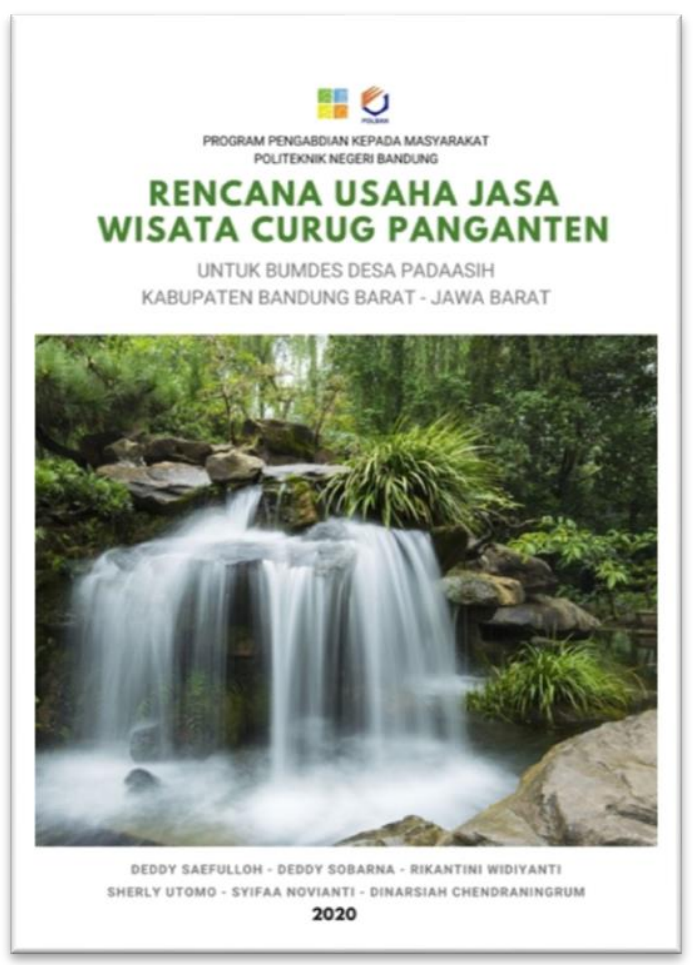

Gambar 3. Cover Dokumen Rencana Usaha Jasa Wisata Curug Panganten

Perguruan Tinggi sebagai bagian dari masyarakat memiliki kewajiban memberikan hasil kajian akademik yang dapat menjadi solusi dalam permasalahan yang dihadapi masyarakat, termasuk masyarakat di daerah pedesaan. Hal inilah yang diwujudkan dalam kegiatan Pengabdian Kepada Masyarakat (PKM) Politeknik Negeri Bandung bersama BUMDES Desa Padaaasih di Kabupaten Bandung Barat

Kegiatan PKM menghasilkan sebuah Rencana Usaha Jasa Wisata yang telah disepakati bersama dan dilatihkan penggunaannya melalui Bimbingan Teknis Kewirausahaan kepada pengurus dan penggerak BUMDES Desa Padaasih. Beberapa modul yang diajarkan pada kegiatan ini mencakup Pemasaran, Strategi Bisnis, Pengelolaan SDM, Pengelolaan Produk, Pengelolaan Operasional Teknis, dan Alat Pemasaran. Sementara itu, dokumen Rencana Usaha Jasa Wisata menjadi 
pedoman yang diserahterimakan kepada pihak BUMDES untuk menjadi panduan agar BUMDES Desa Padaasih Cisarua KBB dapat mengembangkan usaha wisata Curug Panganten serta wisata desa lainnya.

Dengan dilakukannya Kegiatan PKM diharapkan dapat meningkatkan aktivitas masyarakat dalam pengelolaan BUMDES sehingga perekonomian masyarakat desa dapat meningkat dan dapat mensejahtaerakan masyarakat desa. Sehingga nantinya BUMDES dapat berkembang dan menjadi penopang perekonomian desa.

\section{UCAPAN TERIMA KASIH}

Penyusun mengucapkan terima kasih kepada Pusat Penelitian dan Pengabdian kepada Masyarakat Politeknik Negeri Bandung yang telah memberikan dukungan pendanaan tahun 2020. Ucapan terima kasih juga disampaikan kepada Kepala Desa Padasih dan BUMDES Padaasih telah menjadi mitra dengan memberikan kontribusi praktis untuk mengembangkan Rencana Usaha Jasa Wisata Curug Panganten dan telah melakukan praktik Bimbingan Teknis guna mendukung kegiatan PKM ini dalam usaha pengembangan BUMDES Padaasih.

\section{DAFTAR PUSTAKA}

[1] Permendesa, 2015, PDTT Nomor 4 Tahun 2015 tentang Badan Usaha Milik Desa. Permendesa: Jakarta.

[2] Ambrose, G. and P. Harris, 2010, Basics Design 08: Design Thinking. Lausanne: AVA Publishing.

[3] Amrial, M.E. and A.M. Adrian, 2017, Penta helix model: A sustainable development solution through the industrial sector. Social and Human Sciences.

[4] DeCenzo, D.A., S.P. Robbins, and S.L. Verhulst, 2016, Fundamentals of human resource management. John Wiley \& Sons.

[5] Volgger, Michael, and H. Pechlaner, 2014, Requirements for destination management organizations in destination governance: Understanding DMO success. Tourism Management, 41: p. 64-75.

[6] Munar, A.M., 2012. Social media strategies and destination management. Scandinavian Journal of Hospitality and Tourism, 12(2): p. 101-120. 